\title{
Microstructural Evolution of X20CrMoV12.1 Steel upon Short-term Creep Rupture Test
}

\author{
Mariko Hino, Yinsheng He, Kejian Li, Jungchel Chang ${ }^{1}$, Keesam Shin* \\ School of Nano \& Advanced Materials Engineering, Changwon National University, Changwon 641-773, Korea \\ ${ }^{1}$ Power Generation Laboratory, Korea Electric Power Research Institute, Daejeon 305-760, Korea
}

*Correspondence to:

Shin K,

Tel: +82-55-213-3696

Fax: $+82-55-261-7017$

E-mail: keesam@changwon.ac.kr

Received December 19, 2013

Revised December 26, 2013

Accepted December 26, 2013
In this work, microstructural and hardness evolution of the X20 steel upon short-term creep test $\left(550^{\circ} \mathrm{C}\right.$ to $650^{\circ} \mathrm{C}, 180^{\circ} \mathrm{C}$ to $\left.60 \mathrm{MPa}\right)$ was studied by using scanning electron microscope, electron backscattered diffraction, and transmission electron microscope, microhardness tester. After creep rupture, gauge and grip part of the specimens were microstructurally analyzed. Creep at the $650^{\circ} \mathrm{C} / 60 \mathrm{MPa}$ resulted in a rupture at 1,460 hours with growth of lath width from 1.31 to $2.87 \mu \mathrm{m}$ and a grain growth with a more equiaxed feature. There is a close relationship between Microhardness and lath width. The formation and coarsening of Laves phase, which was observed up to $600^{\circ} \mathrm{C}$ of creep temperature, was accelerated by the applied stress. Slight coarsening of the $\mathrm{M}_{23} \mathrm{C}_{6}$ was observed in the $550^{\circ} \mathrm{C}$ and $600^{\circ} \mathrm{C}$ crept or aged specimens. The coarsening of $\mathrm{M}_{23} \mathrm{C}_{6}$ depended on the temperature, where specimens crept at $650^{\circ} \mathrm{C}$ showed higher growth rate. The microstructural evolution of X20 after short-term creep test was extensively discussed in relation to the long-term creep/aging test reported in literatures.

Key Words: $12 \%$ Cr, Creep, Microstructure, Laves phase, Microscopy

\section{INTRODUCTION}

For coal fired power plants, increasing efficiency is essential to reduce pollution and expense, for which increase of the steam temperature is often applied. Power generation at higher temperature requires development of more durable/reliable materials and assessment of degradation of parts used at the high temperature. Creep is one of the most prominent failure types of materials. For the development of high temperature materials or efficient maintenance of them require through understanding the degradation mechanism of materials such as creep, which has long been studied. Tempered martensitic ferritic steels of $9 \%$ to $12 \%$ Cr represent very important high temperature materials in fossil-fired power plants operating in the temperature up to $630^{\circ} \mathrm{C}$ and a steam pressure greater than $30 \mathrm{MPa}$ (Klotz et al., 2008). The X20CrMoV12.1 steel, typical $10 \%$ to $12 \% \mathrm{Cr}$ heat resistant steels, has been widely used as heat exchanger (superheater, reheater), steam pipes/ tubes, boilers and turbine parts (Hald, 2008). The alloy has typical strengthening element such as; i) solid solution by the high content of $\mathrm{Cr}, \mathrm{Mo}$, ii) refined grains by the formation of tempered martensitic lath structure, iii) precipitation of the uniform dispersion of $\mathrm{M}_{23} \mathrm{C}_{6}(\mathrm{M}$ : $\mathrm{Fe}, \mathrm{Cr}, \mathrm{Mo})$ carbides and MX carbonitrides ( $\mathrm{M}: \mathrm{Nb}, \mathrm{V}, \mathrm{Ti}, \mathrm{X}: \mathrm{C}, \mathrm{N})$, and iv) high dislocation density in the lath matrix. The inhibition of migration of dislocation/grain boundary, recovery, and annihilation of dislocation by precipitates is considered to be the predominant mechanism of strengthening (Abe, 2004; Aghajani et al., 2009a; Cui et al., 2010; Ghassemi-Armaki et al., 2010; Panait et al., 2010a; Payton et al., 2012). The creep resistance depends on the stabilities of the microstructure, especially the $\mathrm{M}_{23} \mathrm{C}_{6}$ precipitates (Eggeler, 1989; Tak et al., 2009; Ghassemi-Armaki et al., 2010; Ghassemi-Armaki et al., 2011; Ghassemi-Armaki et al., 2013). During service or creep test, the main degradation mechanisms has been found to be; i) the formation and growth of Laves phase in various grain

This research was supported by the National Research Foundation of Korea (NRF) grant funded by the Korea government (MEST) (No. 2011-0030803).

(.) This is an open-access article distributed under the terms of the Creative Commons Attribution Non-Commercial License (http://creativecommons.org/licenses/by-nc/3.0) which permits unrestricted noncommercial use, distribution, and reproduction in any medium, provided the original work is properly cited.

Copyrights @ 2013 by Korean Society of Microscopy 
boundaries by consumption of $\mathrm{Cr}$ from the matrix or adhered $\mathrm{M}_{23} \mathrm{C}_{6}$ (Aghajani et al., 2009b; Payton et al., 2012), providing additional nucleation sites of creep cavity propagation (He et al., 2011), ii) growth and agglomeration of $\mathrm{M}_{23} \mathrm{C}_{6}$ decreasing the pinning effect of dislocation and boundaries of grain and lath (Eggeler, 1989; Klotz et al., 2008; Aghajani et al., 2009b; Panait et al., 2010b; Ghassemi-Armaki et al., 2011; GhassemiArmaki et al., 2013).

To date, extensive works have been reported, i.e., relationship between the hardness and the fraction of creep rupture time (Ghassemi-Armaki et al., 2013). The microstructural evolution of the X20 steel upon long-term creep test (Abe, 2004; Hald, 2008; Sonderegger et al., 2008) and on-site service exposure (He et al., 2011). Furthermore, with the development of electron backscattered diffraction (EBSD) techniques (Kim et al., 2013), increasing number of studies on the ferritic grains, lath widths and grain boundaries after creep or aging has been reported (Endo et al., 2003; Abe, 2004; Sonderegger et al., 2007; Rojas et al., 2011). However, some of the findings are still controversial.

The objectives of this study are determination of the effects and influence of each elements on creep behavior; i) the microstructural evolution of X20 steel upon short-term creep, ii) the relationship between the low angle grain boundary (LAGB) and creep/aging, iii) the relationship of hardness and lath width, and iv) the temperature/stress/time effect on the microstructural/creep behavior.

\section{MATERIALS AND METHODS}

The specimens used in the present work were the X20 steel (Table 1). Creep tests on X20 were carried out at elevated temperatures under constant stresses (Table 2). In addition, the X20 specimens were aged at comparable temperature for comparable time (named as 'aged' hereafter) (Table 2). Both the gauge and grip parts ('gauge' and 'grip', respectively, hereafter) of the creep ruptured specimens and just aged specimens were analyzed and compared.

Microstructural study of the test specimens included optical microscope (OM), scanning electron microscope (SEM; Jeol, Tokyo, Japan) with energy dispersive spectrometer (EDS; Inca, Oxford, UK), EBSD (attached in a field emission SEM [FESEM], MIRA II LMH; Tescan, Brno, Czech) and transmission electron microscope (TEM, JEM-2100F; Jeol, Tokyo, Japan) equipped with EDS (Oxford Inca). For OM and SEM observation, specimens were polished and etched with Vilella's reagent $(100 \mathrm{~mL}$ ethanol $+1 \mathrm{~g}$ picric acid +5 $\mathrm{mL} \mathrm{HCl}$ ). Specimens for EBSD analysis were finished with polishing with colloidal silica for 2 hours. TEM specimens were jet-polished using an electrolyte of 5\% perchloric acid and $95 \%$ acetic acid at room temperature. The precipitates characterization was carried out using selected area diffraction pattern and EDS analysis. The quantitative data pertaining to $\mathrm{M}_{23} \mathrm{C}_{6}$, were measured via manual outlining on the TEM micrographs at various magnifications and using the Image

Table 1. Chemical composition (wt\%) of X20

\begin{tabular}{cccccccccc}
\hline $\mathrm{C}$ & $\mathrm{Mn}$ & $\mathrm{P}_{\max }$ & $\mathrm{S}_{\max }$ & $\mathrm{Si}_{\max }$ & $\mathrm{Cr}$ & $\mathrm{Mo}$ & $\mathrm{V}$ & $\mathrm{Ni}$ & $\mathrm{Fe}$ \\
\hline $0.17 \sim 0.23$ & $0.40 \sim 0.70$ & 0.03 & 0.03 & 0.50 & $10.0 \sim 12.50$ & $0.80 \sim 1.25$ & $0.25 \sim 0.35$ & $0.30 \sim 0.80$ & Balance \\
\hline
\end{tabular}

Table 2. X20 specimens in this study with measured average hardness, fraction of LAGB and lath width

\begin{tabular}{|c|c|c|c|c|c|c|c|c|c|}
\hline \multirow[b]{2}{*}{ No.* } & \multicolumn{3}{|c|}{ Processing parameter } & \multicolumn{2}{|c|}{ Microhardness $\left(\mathrm{H}_{\mathrm{V}}\right)$} & \multicolumn{2}{|c|}{ Lath width (nm) } & \multicolumn{2}{|c|}{ Fraction of LAGB (\%) } \\
\hline & $\begin{array}{c}\text { Temperature } \\
\left({ }^{\circ} \mathrm{C}\right)\end{array}$ & $\sigma(\mathrm{MPa})$ & $\mathrm{T}(\mathrm{hr})$ & Gauge & Grip & Gauge & Grip & Gauge & Grip \\
\hline 1 & - & 0 & 0 & - & 234.0 & - & $1,310.8$ & - & 30.7 \\
\hline 2 & 550 & 200 & 2,445 & 241.0 & 251.5 & $1,515.4$ & $1,445.2$ & 32.8 & 31.4 \\
\hline 3 & - & 180 & 6,886 & 236.0 & 250.3 & $1,209.9$ & $1,683.6$ & 31.2 & 33.9 \\
\hline 4 & 600 & 130 & 707 & 220.9 & 250.7 & $1,582.0$ & $1,364.7$ & 30.3 & 40.9 \\
\hline 5 & - & 100 & 6,017 & 210.1 & 248.8 & $1,678.3$ & $1,991.2$ & 29.7 & 34.4 \\
\hline 6 & 650 & 60 & 1,460 & 181.0 & 218.1 & $2,873.3$ & $1,820.6$ & 30.7 & 33.8 \\
\hline 7 & 610 & - & 6 & - & 245.3 & - & $1,992.6$ & - & 30.6 \\
\hline 8 & - & - & 655 & - & 238.9 & - & $1,890.6$ & - & 31.5 \\
\hline 9 & - & - & 6,072 & - & 239.6 & - & $2,168.1$ & - & 31.9 \\
\hline 10 & 660 & - & 6 & - & 240.8 & - & $1,604.0$ & - & 32.8 \\
\hline 11 & - & - & 3,023 & - & 213.6 & - & $1,991.4$ & - & 30.4 \\
\hline 12 & - & - & 6,072 & - & 206.2 & - & $2,212.6$ & - & 31.9 \\
\hline
\end{tabular}

LAGB, low angle grain boundary. ${ }^{*} 1 \sim 6$ : creep rupture tested, 7 12: aged. 
ProPlus 5.0 software (Medica Cybernetics Inc., Silver Spring, MD, USA). The Laves phase, which is larger, was measured using SEM backscattered electron (BSE) images taken from the as-polished specimens. The microhardness of the test specimens was averaged after 10 measurements with a load of 200 kgf.

\section{RESULTS AND DISCUSSION}

\section{Lath Width, Low Angle Grain Boundary, and Hardness}

Fig. 1, EBSD micrographs of the creep test specimens with highlights on grain boundary misorientation, clearly shows that the prior austenite grain boundary (PAGB), lath boundary as well as the subgrain boundary. After creep test, an obvious coarsening of the lath width was observed only in the $650^{\circ} \mathrm{C} / 60 \mathrm{MPa}$ gauge specimen (Fig. 1F1). Clearly, the growth of lath and the grains became more equaixed (as $\mathrm{A} \rightarrow \mathrm{F}$ ) and grain boundaries became less apparent after creep rupture test. The grain morphologies upon long-term creep test ( $\sim 140,000$ hours) at $550^{\circ} \mathrm{C}$ was reported as there is little change of the grain morphologies by Aghajani et al., (2009b). However, the short-term (1,460 hours) creep rupture test at $650^{\circ} \mathrm{C}$ in this work showed a considerable change in the microstructure, which was believed to be the result of the accelearted recovery process at $650^{\circ} \mathrm{C}$ (Dong et al., 2013). Table 2 shows the quantitative measurement of the hardness, lath width, LAGB fraction of the crept or aged specimens. It was reported that the coarsening of lath width after creep test, which was further accelerated by the increase in creep stress
(Endo et al., 2003; Abe, 2004). However, by comparative study of the crept and aged specimens (Table 2, column 7 and 8), it is clear that the value of the lath width of the crept specimens does not have higher value than that of the aged specimens, i.e., the $550^{\circ} \mathrm{C} / 180 \mathrm{MPa}$ and $600^{\circ} \mathrm{C} / 100 \mathrm{MPa}$ crept specimens. Compared to the high coarsening rate of lath in the $650^{\circ} \mathrm{C}$ crept specimen, a slight coarsening of the lath was observed in the $550^{\circ} \mathrm{C}$ and $600^{\circ} \mathrm{C}$ specimens. Besides, it was found the lath width increased with the increase of the creep temprature. Creep test at $650^{\circ} \mathrm{C}$, the coarsening of the lath with the increase of strain were agreed well with previous report (Dong et al., 2013). Abe (2004) and Chen et al. (2011) proposed that the coarsening of lath was due to the progressive localcoalescence of two adjacement lath boundaries near the Y-junction, that causes the movement of Y-junction during recovery process under creep or aging. Both of them pointed out the importance of carbides in pining the lath boundaries and Y-junction as well as the excess dislocation during creep or aging.

The decrease of the hardness of X20 steel upon long-term creep test (Aghajani et al., 2009b) or long-term on-site service (He et al., 2011) was reported. Authors (Endo et al., 2003; Aghajani et al., 2009b; Ghassemi-Armaki et al., 2010; Ghassemi-Armaki et al., 2011) also found that the creep stress accelerated the degradation of hardness. In Table 2 (column 5 and 6), it is to see that the aged specimens owned a higher hardness value than that of the crept, which agreed with the literatures. However, after short-term creep/aging, the decreasing trend in hardness is less obvious.

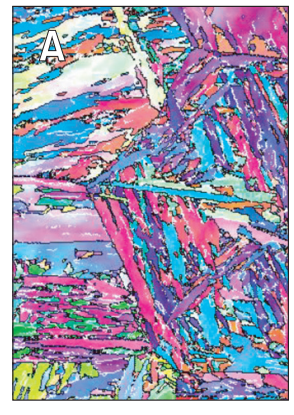

Ferrite
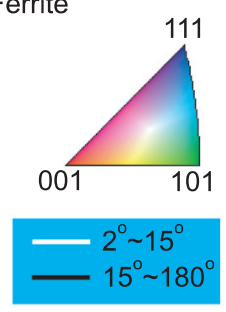

$20 \mu \mathrm{m}$
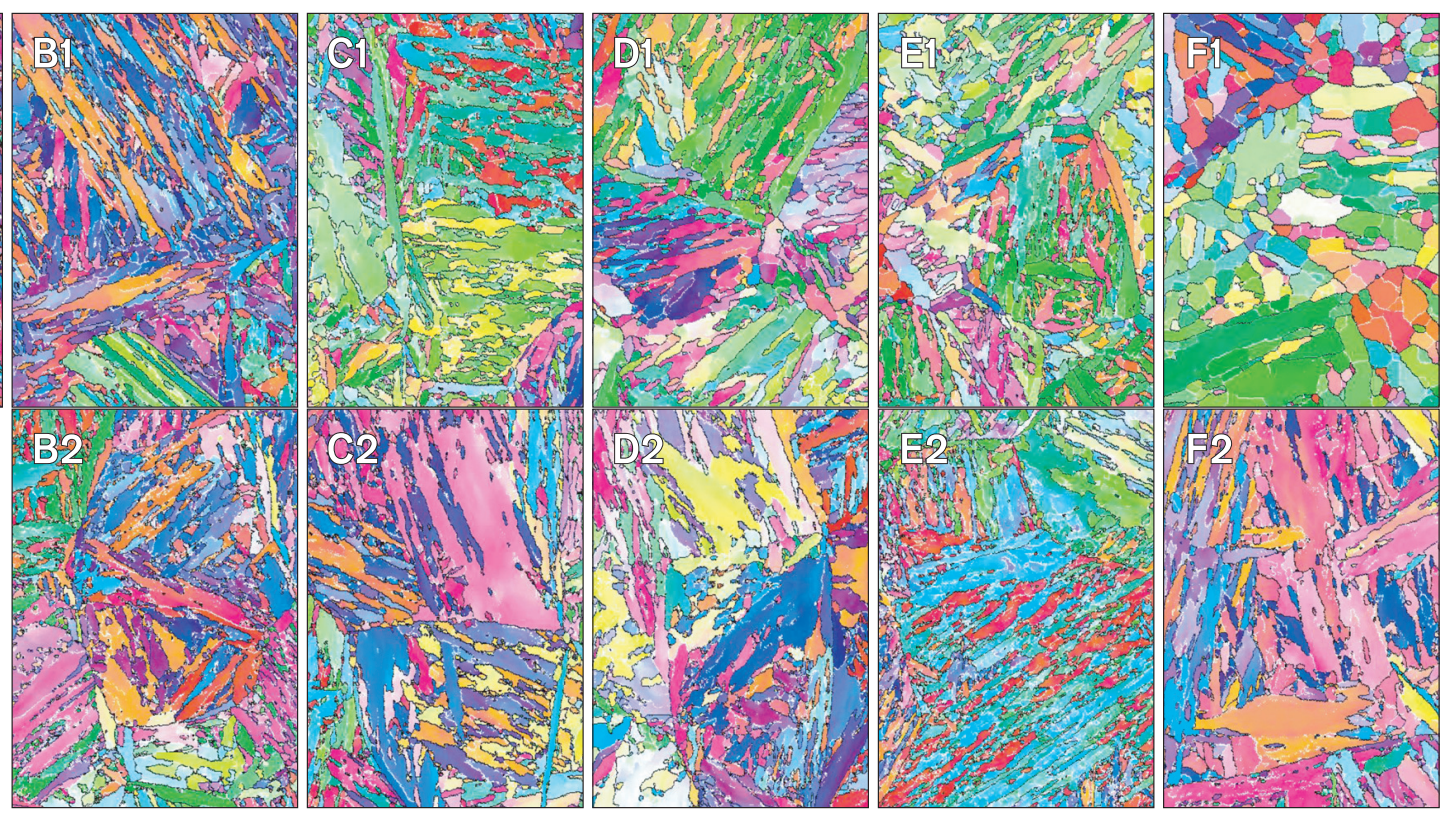

Fig. 1. Inverse pole figure color-coded electron backscattered diffraction micrographs of grain misorientation: (A) new, and the crept specimens (" 1 ": gauge, "2": grip part): (B) $550^{\circ} \mathrm{C} / 180 \mathrm{MPa} / 6,886$ hours, (C) $550^{\circ} \mathrm{C} / 200 \mathrm{MPa} / 2,445$ hours, (D) $600^{\circ} \mathrm{C} / 100 \mathrm{MPa} / 6,017 \mathrm{hours}$, (E) $600^{\circ} \mathrm{C} / 130 \mathrm{MPa} / 707 \mathrm{hours}$, and (F) $650^{\circ} \mathrm{C} / 60 \mathrm{MPa} / 1,460$ hours. 


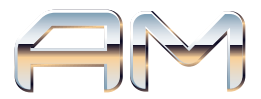

Fig. 2 shows the hardness of the crept and the aged X20 specimens as function of lath. Fig. 2 is a plot of the hardness $(H)$ versus lath width $\left(L_{d}\right)$ of the specimens, between a which a relation can be expressed as the following:

$$
H=\mathrm{B}+\kappa / L_{d}
$$

where $B$ is a constant of 141 , which agrees well with previous study (Ghassemi-Armaki et al., 2013). The $\kappa$ is also a constant, calculated as $1.41 \times 10^{5} \mathrm{~nm}$. The result of Aghajani et al. (2009b) and Eggeler (1989) is shown in Fig. 2, which also fit well to equation (1).

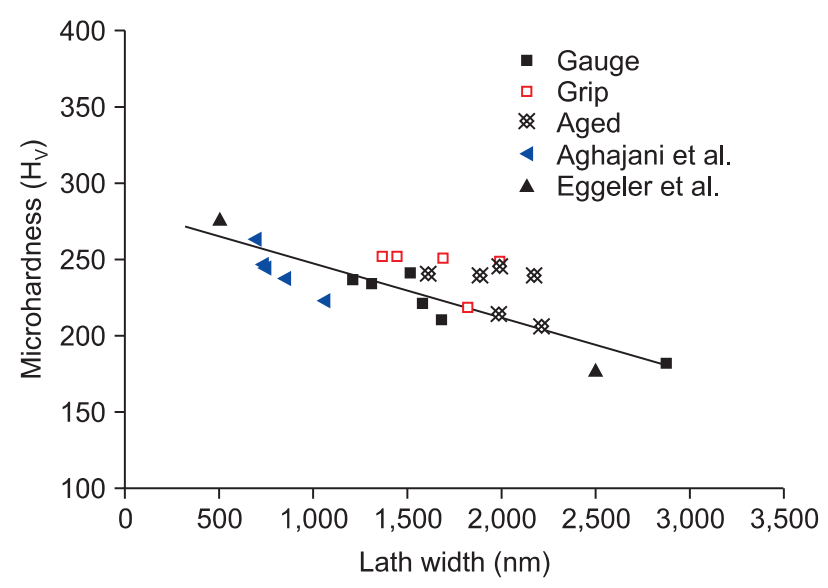

Fig. 2. Relations of the measured hardness and lath width of the X20 specimens.
Maruyama (Ghassemi-Armaki et al., 2013) proposed the following correlation of hardness and creep rupture time $\left(\mathrm{t}_{\mathrm{r}}\right)$ of the $9 \%$ Cr heat resistant steel:

$$
H / \mathrm{H}_{0}=0.98-0.15\left(\mathrm{t} / t_{r}\right)
$$

where $H$ is the hardness $\left(\mathrm{H}_{\mathrm{V}}\right)$ at the time of creep exposure $(\mathrm{t})$, and $\mathrm{H}_{0}$ is the hardness at the initial (un-used) state. Therefore, it is possible to estimate the creep rupture time (or residual lifetime) based on the microstructural parameters $\left(L_{d}\right)$ in combination of equation (1) and (2).

It is well known that the LAGB $\left(2^{\circ}\right.$ to $15^{\circ}$ misorientation $)$ is composed of dislocation cell, subgrain boundary, a part of the precipitate-free lath boundary in $9 \%$ to $12 \% \mathrm{Cr}$ creep resistant steel (Sonderegger et al., 2007; Tak et al., 2009; Payton et al., 2012), which can be clearly revealed by EBSD study (Sonderegger et al., 2008). For example, Panait et al. (2010a, 2010b) reported the decrease of the fraction of LAGB in the grade 91 and 92 creep resistant steel after long-term aging/or creep test (100,000 hours), where the applied stress further accelerated the decrease. On the contrary, the fraction of LAGB increased after long-term creep test of X20 steel, which remained constant upon long-term aging (Aghajani et al., 2009b). As column 9 and 10 in Table 2 show, the fraction of LAGB varies, but close relationship with the processing parameters (i.e., temperature, creep, aging, or time) was not clear.
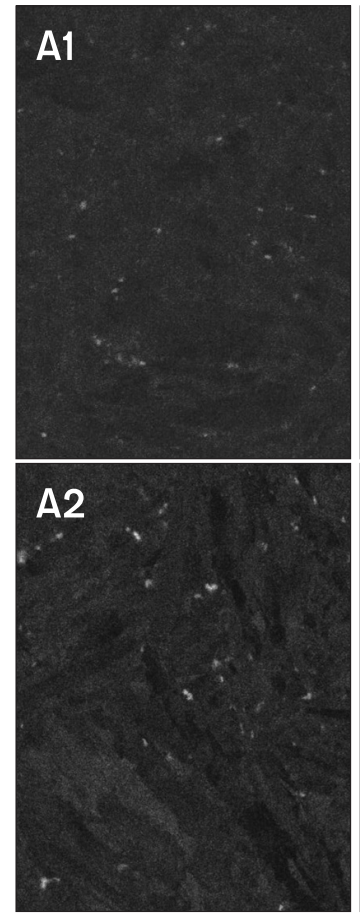
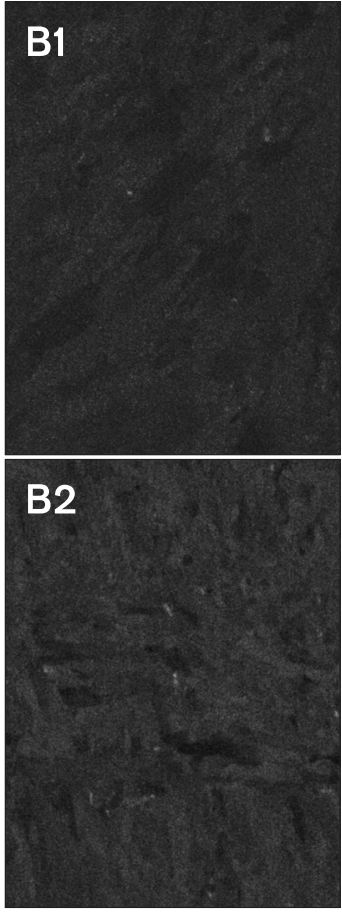
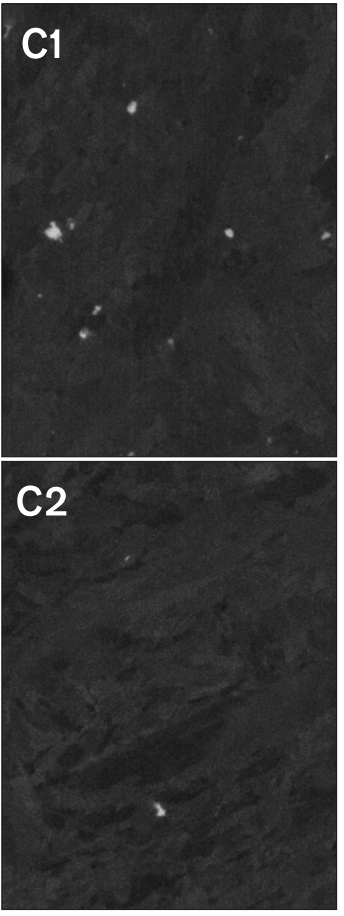
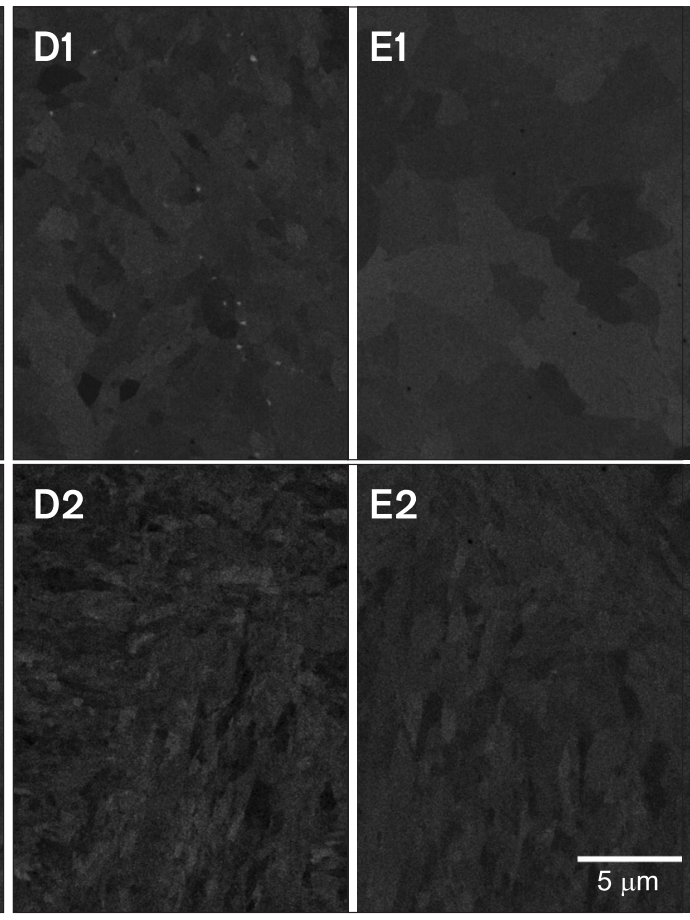

Fig. 3. Typical backscattered electron micrographs of the crept specimens ("1": gauge, "2": grip part): (A) $550^{\circ} \mathrm{C} / 180 \mathrm{MPa} / 6,886 \mathrm{hours}$, (B) $550^{\circ} \mathrm{C} / 200$ $\mathrm{MPa} / 2,445$ hours, (C) $600^{\circ} \mathrm{C} / 100 \mathrm{MPa} / 6,017$ hours, (D) $600^{\circ} \mathrm{C} / 130 \mathrm{MPa} / 707$ hours, and (E) $650^{\circ} \mathrm{C} / 60 \mathrm{MPa} / 1,460 \mathrm{hours}$. 


\section{Laves Nucleation and Growth}

Fig. 3 shows the BSE images of the crept specimens at the gauge and grip parts. The bright particles at the micrographs are Laves phase. It is notable that there is no Laves phase formed in the new X20 specimen. Obviously, Laves phase was observed with variation in size and volume fraction in both of the gauge and grip portions of the $500^{\circ} \mathrm{C} / 180$ to $200 \mathrm{MPa}$ (Fig. $3 \mathrm{~A} 1-\mathrm{C} 2$ ), and the gauge portion of $600^{\circ} \mathrm{C} / 100 \mathrm{MPa}$ (Fig. 3D1) specimens. No Laves were observed in the grip portions of the $600^{\circ} \mathrm{C} / 100 \mathrm{MPa}$ or $650^{\circ} \mathrm{C} / 60 \mathrm{MPa}$ crept specimens. Careful observations indicated that the sizes of the Laves phases in the grip and gauge parts of $550^{\circ} \mathrm{C} / 200 \mathrm{MPa}$ specimens (Fig. $3 \mathrm{~B} 1$ and $\mathrm{B} 2$ ) are small at about the same size, whose edges were not well defined, indicating that it may be at the initial stage of the Laves phase formation. On the other hand, the Laves phase in the $550^{\circ} \mathrm{C} / 180 \mathrm{MPa}$ (Fig. $3 \mathrm{~A} 1$ and B1) crept specimen had clear outlines with wide size range, suggesting that they are growing, which reached to a grown state in the $600^{\circ} \mathrm{C} / 100 \mathrm{MPa}$ specimen.

A lot of previous studies reported the formation of Laves phase (200 to $400 \mathrm{~nm}$ ) in $9 \%$ to $12 \%$ Cr heat resistant steel upon aging or creep in grown state was generally distributed on the various boundaries (i.e., PAGB, lath boundary, subgrain boundary, and parts of the LAGB) (Cui et al., 2010; He et al., 2011; Kipelova et al., 2012; Dong et al., 2013). The small Laves phase as shown in Fig. 3B1 and B2 are considered to indicate the initial stage of the Laves phase formation/growth. TEM observation revealed that the initial nuclation location of the Laves was at or near the subgrain bourdaries as shown in Fig. 4A (the same specimen as Fig. 3B1 and B2). As the Laves phase grows, it was also observed at the lath boundary (Figs. $3 \mathrm{~A} 1$ and $\mathrm{A} 2,3 \mathrm{C} 1$ and $\mathrm{C} 2,3 \mathrm{D} 1,4 \mathrm{~B})$ as well as at the PAGB (He et al., 2011; Rojas et al., 2011). The formation of Laves phase primarily at the subgrain boundaries, and the absence of Laves phase in $650^{\circ} \mathrm{C}$ crept specimens may related to the coarsening of the $\mathrm{M}_{23} \mathrm{C}_{6}$ during creep (Cui et al., 2010; Kipelova et al., 2012), which is discussed in the following section.

Fig. 5 shows the quantitative measurement of the Laves phase using BSE images at varioius magnifications. Obviously, the size, area fraction and number density (Fig. 5A-C, respectively) of the Laves phase in the gauge part (solid symbol) are larger than those of the grip part (open symbol), indicating the stress accelerates formation and coarsening of Laves phase, which agrees well with the previous studies (He et al., 2011; Dong et al., 2013) and literatures (i.e., Cui et al., 2010; Kipelova et al., 2012). Furthermore, regarding to the creep stress and rupture time, it seems that with the increase of creep temperature the size of Laves phase increased (Figs. $3 \mathrm{~A} 1-\mathrm{D} 1,5 \mathrm{~A})$ with decrease of the area fraction and number density (see Figs. 3A1-E1, 5B and C), indicating the high coarsening rate in $600^{\circ} \mathrm{C}$ specimens. However, Laves phase was not observed at the $650^{\circ} \mathrm{C}$ crept specimens. The results suggests that the key influence on the nuclation and growth of the Laves phase is the temperature, where creep at lower temperature (or longer rupture time) lead to the formation of higher volume fraction and number density of the Laves phase.

An interesting finding is that the absence of Laves in the specimen aged at a similar temperature and time, the gauge part of $600^{\circ} \mathrm{C} / 100 \mathrm{MPa} / 6,017$ hours crept specimen (Table 2, column 4 and row 7, Fig. 3C2) and the aged specimen of $610^{\circ} \mathrm{C} / 6,072$ hours (Table 2, column 4 and row 11). Laves phase was not observed in the aged specimens $\left(610^{\circ} \mathrm{C} / 6\right.$ hours, 655 hours, $660^{\circ} \mathrm{C} / 6$ hours, etc., Table 2). It was often
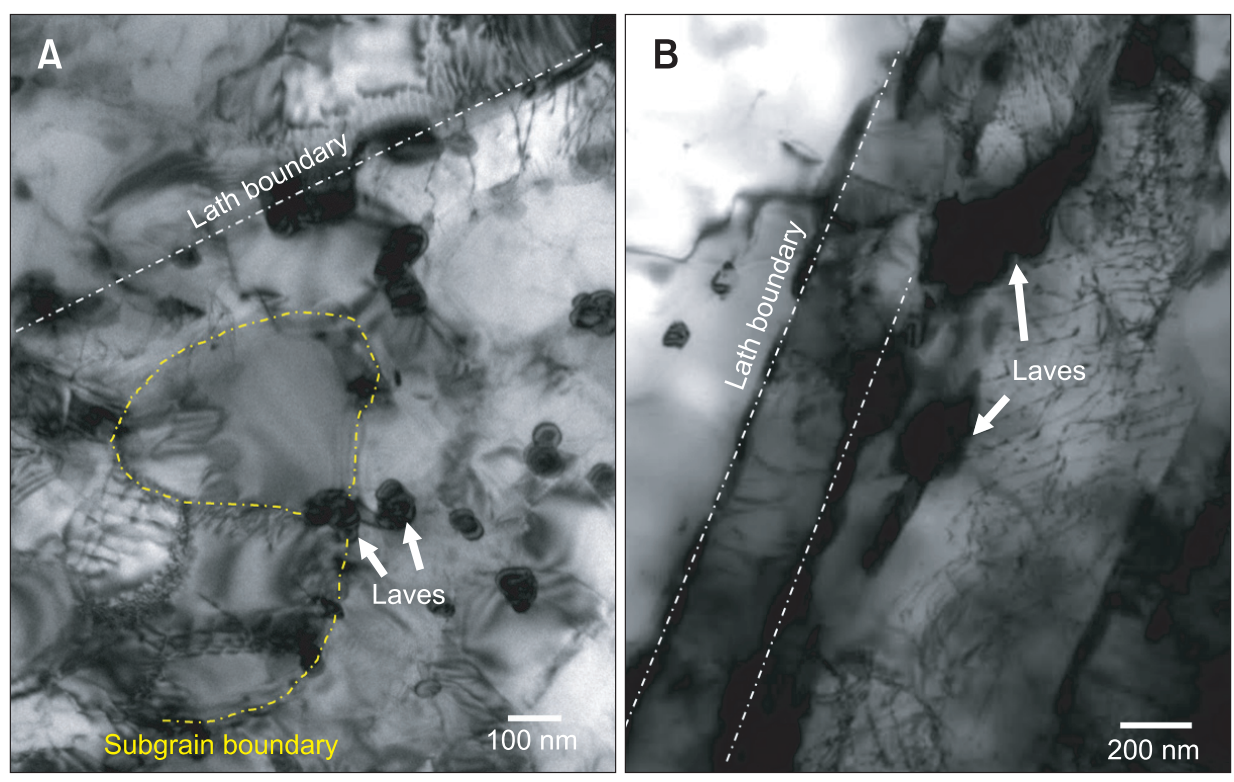

Fig. 4. Typical transmission electron microscope micrographs of the crept X20 specimens. (A) Grip part of $550^{\circ} \mathrm{C} / 200$ $\mathrm{MPa} / 2,445$ hous. (B) Gauge part of $600^{\circ} \mathrm{C} /$ $100 \mathrm{MPa} / 6,017$ hours specimens. 

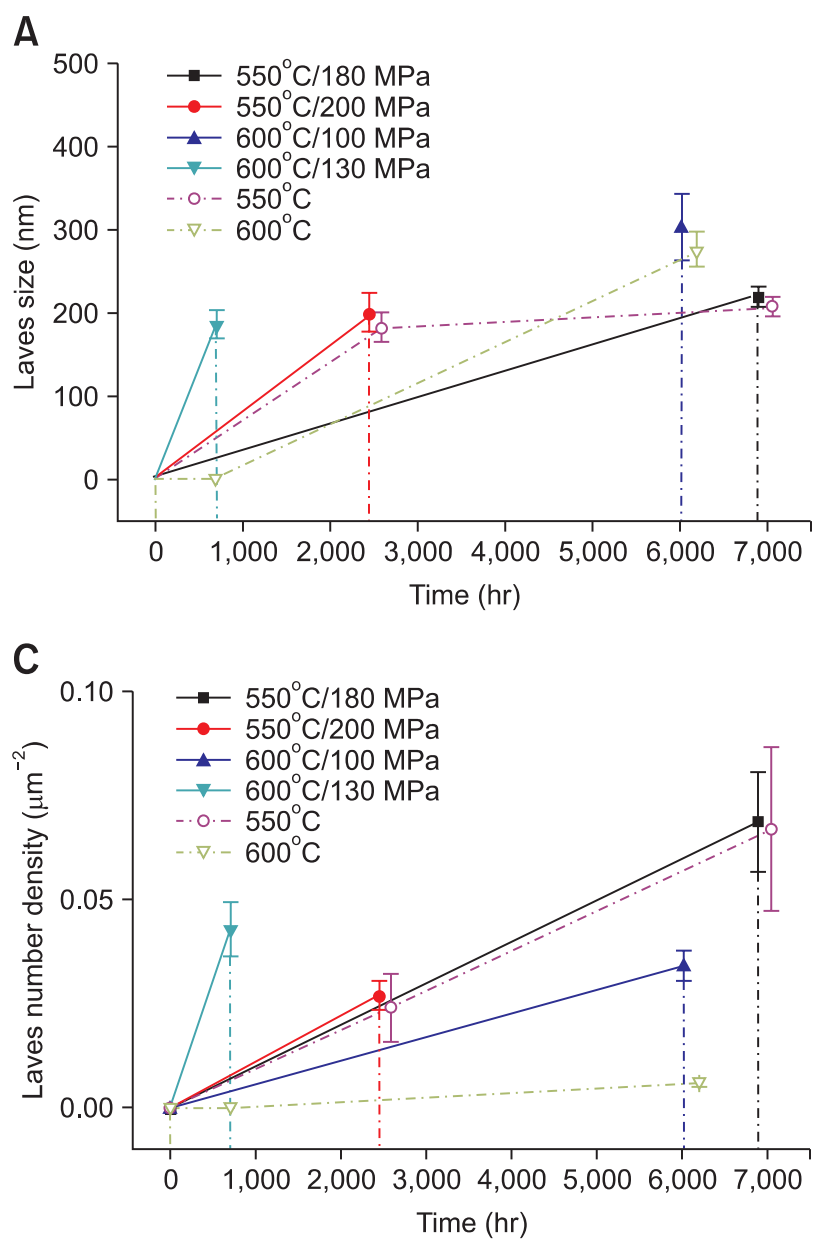

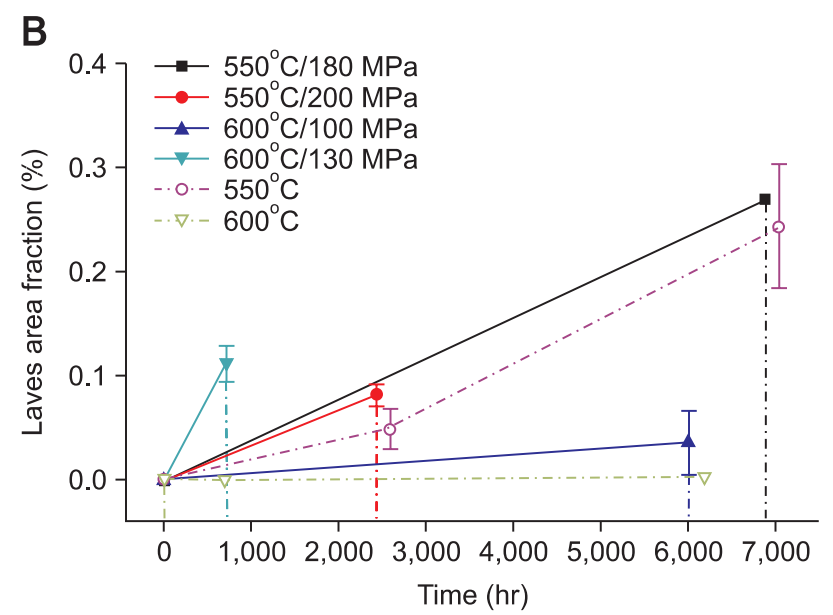

Fig. 5. Evolution of the Laves phase upon short-term creep test of X20. (A) Average size, (B) area fraction, and (C) number density. The filled and open symbol represent the gauge and the grip part, respectively. The $\mathrm{x}$-axis of the grip specimens (time) is shifted a little hereafter for better observation of the error bars.
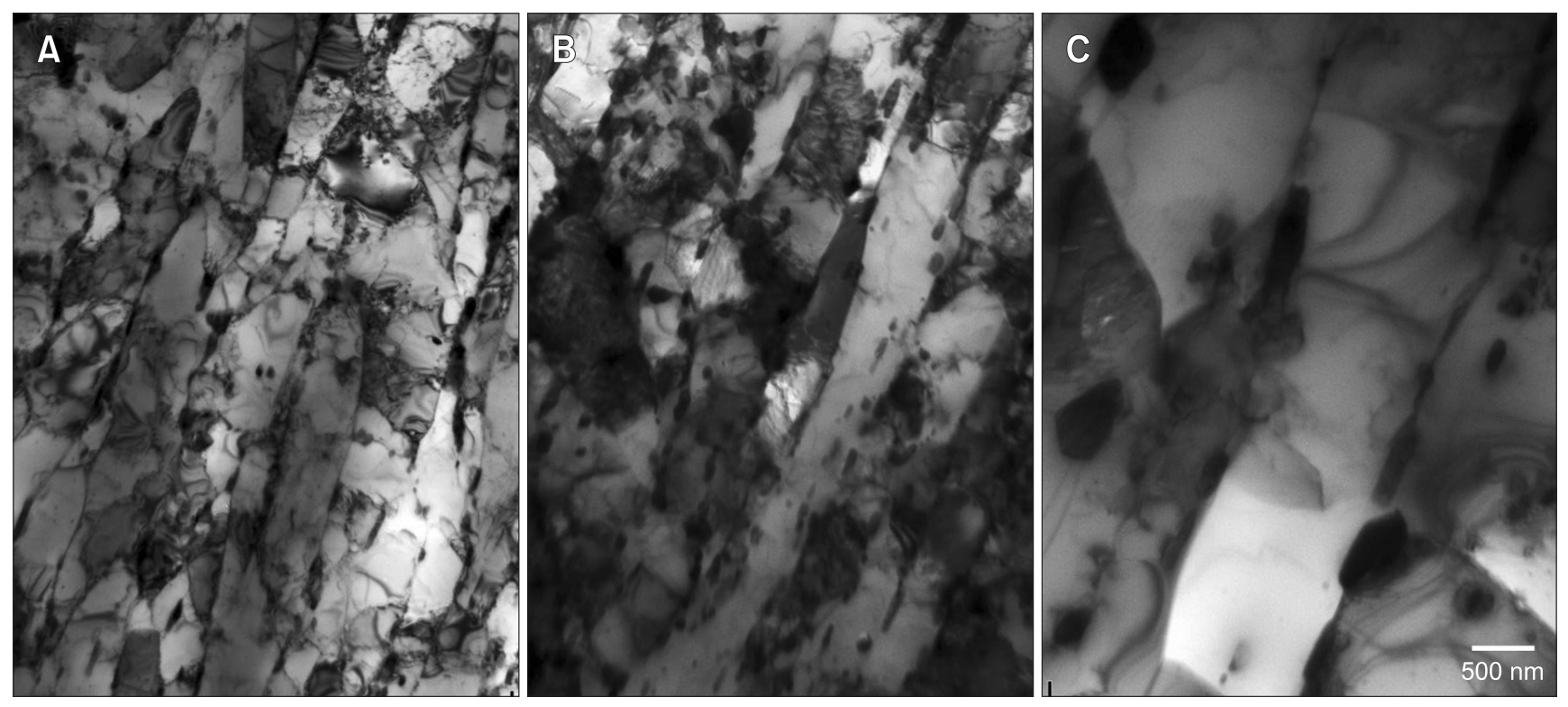

Fig. 6. Typical transmission electron microscope micrographs of the (A) new, and crept specimens of the gauge parts: (B) $550^{\circ} \mathrm{C} / 180 \mathrm{MPa} / 6,886 \mathrm{hours}$, and (C) $650^{\circ} \mathrm{C} / 60 \mathrm{MPa} / 1,460$ hours. 
regarded by researchers (Eggeler, 1989; Endo et al., 2003; Aghajani et al. 2009a, 2009b; Ghassemi-Armaki et al., 2009; Ghassemi-Armaki et al., 2010; Ghassemi-Armaki et al., 2011; Payton et al., 2012; Ghassemi-Armaki et al., 2013) that the gauge portion of the crept specimens is stress-free and used as stress-free aging counterparts. The results shown here suggest that the gauge part of the crept specimens has the stress influence, with evidence that the stress accelerates the formation and growth of the Laves phase.

\section{Evolution of $\mathrm{M}_{23} \mathrm{C}_{6}$}

Fig. 6 is the typical TEM images of the new (Fig. 6A) and crept specimens (for example, gauge parts of the $550^{\circ} \mathrm{C} / 180$ $\mathrm{MPa} / 6,886$ hours and $650^{\circ} \mathrm{C} / 60 \mathrm{MPa} / 1,460$ hours crept). The $\mathrm{M}_{23} \mathrm{C}_{6}$ as shown in Fig. $6 \mathrm{~B}$ coarsened slightly after creep at lower temperature and longer time, while coarsend drasticly at higher temperature even within shorter creep time. The evolution of $\mathrm{M}_{23} \mathrm{C}_{6}$ was carried out by the quantitative analysis as shown in Fig. 7, which clearly reveals the evolution characteristics upon short-term creep, i.e.; i) the gowth of $\mathrm{M}_{23} \mathrm{C}_{6}$ was faster at the $650^{\circ} \mathrm{C}$ (Fig. $6 \mathrm{~A}$ ) resulting in the
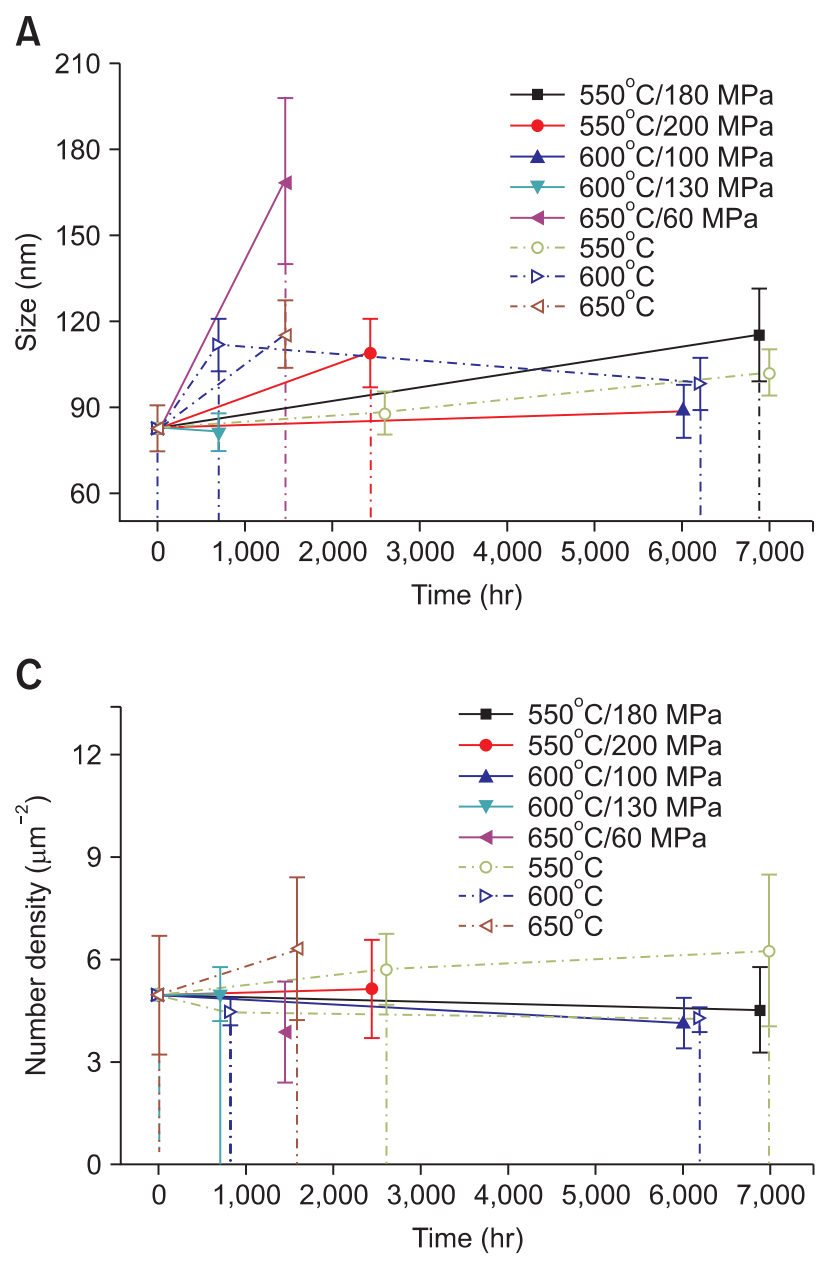

increased area fraction (Fig. 7B), ii) a slight coarsening in the $600^{\circ} \mathrm{C}$ and $550^{\circ} \mathrm{C}$ crept specimens, furthermore, it's observed that the size and area fraction is likely to remain stable after creep at $600^{\circ} \mathrm{C}$, while a little increase of the after size crept at $550^{\circ} \mathrm{C}$, iii) the number density seems to remain stable in all of the crept specimens (note the wide error bar), and iv) the size of the $\mathrm{M}_{23} \mathrm{C}_{6}$ in the gauge portion of the $550^{\circ} \mathrm{C} / 180$ to $200 \mathrm{MPa}, 650^{\circ} \mathrm{C} / 60 \mathrm{MPa}$ crept specimen is larger than the grip one. However, the inverese trend was obtained in other two crept specimens. It was reported the increase of the stress accelerated the coarsening of the $\mathrm{M}_{23} \mathrm{C}_{6}$ during long-term creep test or aging (Eggeler, 1989; Aghajani et al., $2009 \mathrm{~b}$ ). Therefore, the results suggest the stress does not give a signficant effect on the coarsening of $\mathrm{M}_{23} \mathrm{C}_{6}$ during shortterm creep test. In addition, no Z-phase was observed in all of the specimens studied, since the MX precipitates are found to be very stable during short-term test, and even during longterm creep test or on-site service under the temperature of $650^{\circ} \mathrm{C}$ (Eggeler, 1989; Hald, 2008; Aghajani et al., 2009b). The area fraction of $\mathrm{M}_{23} \mathrm{C}_{6}$ crept specimen in $550^{\circ} \mathrm{C}$ to $650^{\circ} \mathrm{C}$ do not show clear trend since their ruptures took place at

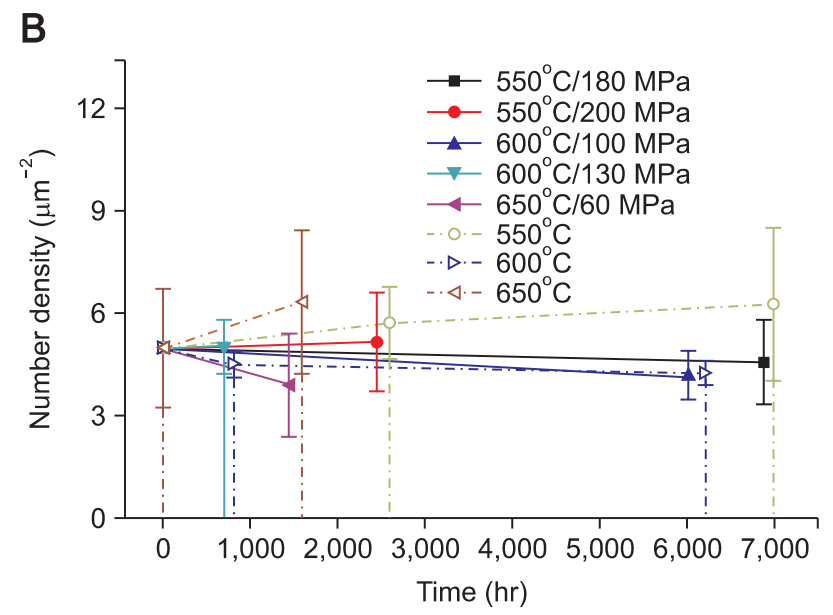

Fig. 7. Evolution of the $\mathrm{M}_{23} \mathrm{C}_{6}$ upon short-term creep test of X20. (A) Average size, (B) area fraction, and (C) number density. 
different duration. However, the data from the aged specimen clearly indicate higher temperature accelerates precipitation/ growth of $\mathrm{M}_{23} \mathrm{C}_{6}$.

\section{Correlation of Laves Phase and $\mathrm{M}_{23} \mathrm{C}_{6}$}

As shown in Figs. 3 and 5, it is obvious that; i) in $650^{\circ} \mathrm{C}$ crept specimens, no Laves phase formed, meanwhile, coarse and high volume fraction of $\mathrm{M}_{23} \mathrm{C}_{6}$ was observed (Fig. 7A and $\mathrm{B}$ ), ii) increase of creep temperature from $550^{\circ} \mathrm{C}$ to $600^{\circ} \mathrm{C}$ causes the increase of the size, and the decrease of area fraction and the number density of Laves phase (Figs. 3, 5B and C). These were considered as the results of competitive growth of $\mathrm{M}_{23} \mathrm{C}_{6}$ and Laves phase.

Ghassemi-Armaki et al. (2009) reported that the $\mathrm{M}_{23} \mathrm{C}_{6}$ remained stable even after aging at $650^{\circ} \mathrm{C}$ upto 20,000 hours in a similar $12 \% \mathrm{Cr}$ steel. Futhermore, when crept under $550^{\circ} \mathrm{C} / 120 \mathrm{MPa}$ for 12,456 hours, the average size of the $\mathrm{M}_{23} \mathrm{C}_{6}$ only changed from $166 \mathrm{~nm}$ to $170 \mathrm{~nm}$ (Aghajani et al., 2009b). In the present work, even the size of $\mathrm{M}_{23} \mathrm{C}_{6}$ coarsened a little after crept at $550^{\circ} \mathrm{C}$ and $600^{\circ} \mathrm{C}$.

As Cui et al. (2010) has reported, the absence of the Laves phase in the $650^{\circ} \mathrm{C}$ crept specimen is considered to be based on the depletion of $\mathrm{Cr}$ on the grain boundary region due to the formation growth of $\mathrm{M}_{23} \mathrm{C}_{6}$. The stability of Laves phase at $550^{\circ} \mathrm{C}$ can be understood considering the minimal growth of $\mathrm{M}_{23} \mathrm{C}_{6}$ in the specimen crept (Fig. 7). During creep test at $550^{\circ} \mathrm{C}$, there would be abundant sites for the Laves phase nuclation and growth due to the high $\mathrm{Cr}$ content in the grain boundary region, resulting in the high density and area fraction of Laves phase. Besides, as mentioned above, the initial location of the Laves phase was proposed at/or near the subgrain boundary (Fig. 4A), which was attributed to the $\mathrm{Cr}$ in/or near the PAGB, lath boundaries were contributed to the formation of $\mathrm{M}_{23} \mathrm{C}_{6}$ during heat treatment (Kipelova et al., 2012). The larger Laves phase in the $600^{\circ} \mathrm{C}$ crept specimens was considered as evidence of higher coasening rate at higher the temperature (the number densities in the gauge parts of $550^{\circ} \mathrm{C} / 180 \mathrm{MPa}$ and $600^{\circ} \mathrm{C} / 100 \mathrm{MPa}$ specimens are 0.069 and $0.034 \mu \mathrm{m}^{-2}$, respectively). The smaller area fraction of the Laves phase in the $600^{\circ} \mathrm{C}$ crept specimens can be understood in the context of coarsening at high temperature and consumption of $\mathrm{Cr} / \mathrm{C}$ by $\mathrm{M}_{23} \mathrm{C}_{6}$ (Aghajani et al., 2009b).

\section{SUMIMARY}

In this work, microstructural evolution and its relation to hardness of the X20 steel upon short-term creep test $\left(550^{\circ} \mathrm{C}\right.$ to $650^{\circ} \mathrm{C}, 180$ to $60 \mathrm{MPa}$ ) was studied by using SEM, EBSD and TEM, microhardness tester. After creep, specimens for microstructural characterization were prepared both from gauge and grip part.

- After short-term creep test, there was no clear relationship between the fraction of LAGB and the creep temperature/ stress/time.

- Though the growth of lath width was not obvious at $550^{\circ} \mathrm{C}$ and $600^{\circ} \mathrm{C}$ specimens, it coarsened from 1.31 to $2.87 \mu \mathrm{m}$ and more equiaxed grains were formed after creep at the $650^{\circ} \mathrm{C}$.

- The relation of the Vickers hardness $(H)$ with lath width $\left(L_{d}\right)$ was approximately expressed as a function $H=\mathrm{B}+\kappa / L_{d}$, where $\mathrm{B}(141)$ and $\kappa\left(1.14 \times 10^{5} \mathrm{~nm}\right.$ in this case $)$ is a constant.

- The Laves phase was formed in the $550^{\circ} \mathrm{C}$ and $600^{\circ} \mathrm{C}$ crept specimens. The initial state of Laves formation was found to locate near/at the subgrain or lath boundary.

- The coarsening of Laves depended on the creep temperature, showing a higher coarsening rate at higher temperature up to $600^{\circ} \mathrm{C}$. However, creep at lower temperature lead to form more volume fraction and number density of Laves phase. Comparative study of the gauge and grip part and aged specimens showed that the creep stress accelerates the formation and coarsening of Laves phase.

- Slight coarsening of the $\mathrm{M}_{23} \mathrm{C}_{6}$ was found in the $550^{\circ} \mathrm{C}$ to $600^{\circ} \mathrm{C}$ crept specimens. The coarsening of $\mathrm{M}_{23} \mathrm{C}_{6}$ in the $650^{\circ} \mathrm{C}$ specimen shows much higher than those of $550^{\circ} \mathrm{C}$ and $650^{\circ} \mathrm{C}$. Besides, the MX was very stable during shortterm creep test.

\section{REFERENCES}

Abe $\mathrm{F}$ (2004) Coarsening behavior of lath and its effect on creep rates in tempered martensitic $9 \mathrm{Cr}-\mathrm{W}$ steels. Mater. Sci. Eng. A 387-389, 565-569.

Aghajani A, Richter F, Somsen C, Fries S G, Steinbach I, and Eggeler G (2009a) On the formation and growth of Mo-rich Laves phase particles during long-term creep of a $12 \%$ chromium tempered martensite ferritic steel. Scripta Mater. 61, 1068-1071.

Aghajani A, Somsen C, and Eggeler G (2009b) On the effect of longterm creep on the microstructure of a $12 \%$ chromium tempered martensite ferritic steel. Acta Mater. 57, 5093-5106.
Chen R P, Ghassemi-Armaki H, Maruyama K, and Igarashi M (2011) Long-term microstructural degradation and creep strength in Gr.91 steel. Mater. Sci. Eng. A 528, 4390-4394.

Cui H, Sun F, Chen K, Zhang L, Wan R, Shan A, and Wu J (2010) Precipitation behavior of Laves phase in $10 \% \mathrm{Cr}$ steel X12CrMoWVNbN10-1-1 during short-term creep exposure. Mater. Sci. Eng. A 527, 75057509.

Dong J, He Y, Kim M, and Shin K (2013) Effect of creep stress on the microstructure of $9-12 \% \mathrm{Cr}$ steel for rotor materials. Microsc. Microanal. 19, 95-98. 
Eggeler G (1989) The effect of long-term creep on particle coarsening in tempered martensite ferritic steels. Acta Metall. 37, 3225-3234.

Endo T, Masuyama F, and Park K S (2003) Change in Vickers hardness and substructure during creep of a Mod.9Cr-1Mo steel. Mater. Trans. 44, 239-246.

Ghassemi-Armaki H, Chen R, Kano S, Maruyama K, Hasegawa Y, and Igarashi M (2011) Microstructural degradation mechanisms during creep in strength enhanced high $\mathrm{Cr}$ ferritic steels and their evaluation by hardness measurement. J. Nucl. Mater. 416, 273-279.

Ghassemi-Armaki H, Chen R, Maruyama K, and Igarashi M (2010) Premature creep failure in strength enhanced high $\mathrm{Cr}$ ferritic steels caused by static recovery of tempered martensite lath structures. Mater. Sci. Eng. A 527, 6581-6588.

Ghassemi-Armaki H, Chen R, Maruyama K, and Igarashi M (2013) Contribution of recovery mechanisms of microstructure during longterm creep of Gr.91 steels. J. Nucl. Mater. 433, 23-29.

Ghassemi-Armaki H, Chen R, Maruyama K, Yoshizawa M, and Igarashi M (2009) Static recovery of tempered lath martensite microstructures during long-term aging in 9-12\% $\mathrm{Cr}$ heat resistant steels. Mater. Lett. 63, 2423-2425.

Hald J (2008) Microstructure and long-term creep properties of 9-12\% $\mathrm{Cr}$ steels. Inter. J. Press. Vess. Pip. 85, 30-37.

He Y, Chang J, Dong J, and Shin K (2011) Microstructural evolution of X20CrMoV12.1 steel upon long-term on-site exposure in power plants. Adv. Sci. Lett. 4, 1416-1423.

Kim J H, Kim D I, Kim J S, Choi S H, Yi K W, and Oh K H (2013) Technical investigation into the in-situ electron backscatter diffraction analysis for the recrystallization study on extra low carbon steels. Appl. Microscopy 43, 88-97.

Kipelova A, Belyakov A, and Kaibyshev R (2012) Laves phase evolution in a modified P911 heat resistant steel during creep at 923K. Mater. Sci. Eng. A 532, 71-77.

Klotz U E, Solenthaler C, and Uggowitzer P J (2008) Martensiticaustenitic 9-12\% Cr steels-alloy design, microstructural stability and mechanical properties. Mater. Sci. Eng. A 476, 186-194.

Panait C, Bendick W, Fuchsmann A, Gourgues-Lorenzon A F, and Besson $J(2010 b)$ Study of the microstructure of the grade 91 steel after more than $100,000 \mathrm{~h}$ of creep exposure at $600^{\circ} \mathrm{C}$. Inter. J. Press. Vess. Pip. 87, 326-335.

Panait C, Gourgues-Lorenzon A F, Besson J, Fuchsmann A, Bendick W, Gabrel J, and Piette M (2010a) Long term aging effect on the creep strengthening of the T92 steel. The 9th Liege Conference: Materials for Advanced Power Engineering, Liege, Belgium.

Payton E J, Aghajani A, Otto F, Eggeler G, and Yardley V A (2012) On the nature of internal interfaces in a tempered martensite ferritic steel and their evolution during long-term creep. Scripta Mater. 66, 10451048.

Rojas D, Garcia J, Prat O, Sauthoff G, and Kaysser-Pyzalla A R (2011) 9\% $\mathrm{Cr}$ heat resistant steels: alloy design, microstructure evolution and creep response at $650^{\circ} \mathrm{C}$. Mater. Sci. Eng. A 528, 5164-5176.

Sonderegger B, Mitsche S, and Cerjak H (2007) Martensite laths in creep resistant martensitic 9-12\% Cr steels-Calculation and measurement of misorientations. Mater. Character. 58, 874-882.

Sonderegger B, Mitsche S, and Cerjak H (2008) Microstructural analysis on a creep resistant martensitic $9-12 \% \mathrm{Cr}$ steel using the EBSD method. Mater. Sci. Eng. A 481-482, 466-470.

Tak K G, Schulz U, and Eggeler G (2009) On the effect of micrograin crystallography on creep of FeCr alloys. Mater. Sci. Eng. A 510-511, 121-129. 